\title{
DIFFRACTING REFLECTION: A MOVE BEYOND REFLECTIVE PRACTICE
}

\author{
Veronica Ann Mitchell \\ University of the Western Cape \\ veronicaannmitchell@gmail.com
}

\section{ABSTRACT}

Reflective practice has become a core component in higher education studies. In the health sciences, reflective tasks are required throughout the undergraduate programmes, yet many students struggle to find value in these tasks for their present and future professional practice. Benefits that can be derived from the process are undermined by this lack of motivation for reflective engagement. Concern around the static, contained, individualist nature of reflections that often face judgement through assessment can be addressed by opening up the process to generate new potentials. In this paper, I draw on new materialism and the Baradian (2007) philosophy of diffraction to move beyond the reflective practices of representation and sameness by affirmatively working with/through differences. I refer to data collected in an ethics approved research study at the University of Cape Town (UCT), South Africa, to explain a context of unjust practices in which students learn. I demonstrate how students' reflective texts shared online on the Google Drive platform can be productive and transformative material forces that enact new knowledge, valued by students. The apparatus of text-students-events is put to work creating new possibilities to enable a socially just pedagogy in medical education.

Keywords: reflection; socially just pedagogy; diffraction; Barad; new materialism; affect; medical education; obstetrics

\section{INTRODUCTION}

We're taught reflection as a chore; it's that last thing that you do at the end of the block. To be frank, everyone hates it ... The way that it's given to us is very demeaning to what it's actually doing ... So as the years go by every single time you hear the words evaluation or reflection, your mind already springs to like, aghhh, ag, what do I have to say this time? It's one of those things. I don't think it is very helpful because of the way it's done. (Fourth year student interview 2015)

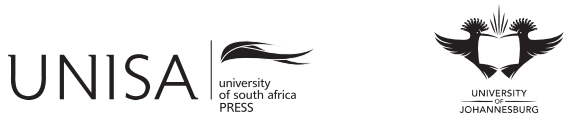

Education as Change 
Teaching reflective practice is not easy, nor is engagement with the reflective process. Yet the impetus for students to learn to be reflective has become an integral component of many professional disciplines, such as management studies, adult education and the health and social sciences. Since John Dewey (1938) introduced reflection as a learning tool to draw personal meaning from experience, many different insights have emerged about reflective practices (see, for example, Argyris and Schön 1974; Brookfield 1995; Habermas 1971; Hatton and Smith 1995; King and Kitchener 1994; Kolb 1984; Moon 2001; Schön 1987). Different pedagogical tools are used to facilitate the reflective process such as Kolb's (1984) four-stage experiential learning cycle and Schön's (1987) time-framed reflective interpretation of an event that considers reflection-inaction and reflection-on-action. These varied and different approaches for teaching reflective practice facilitate students to move beyond description and observation to a deeper learning and interpretation of their encounters. However, as indicated by the student quoted above, the value of reflective curricular tasks is questionable. From my own experience, like many educators instructed to include reflection in curricular programmes, I have struggled to engage students in a meaningful manner. Song and Stewart $(2012,955)$ suggest that "perhaps a reflective writing curriculum should not be expected to be universally accepted and appreciated by students." Such a perspective is understandable yet limiting, with the possibility of marginalising and alienating some students. Rather than normalising such disparities, I propose that more buy-in is likely with a desire to engage with reflective practices if the pedagogical process can be more productive and meaningful for all students.

There appears to be a paucity of publications that explore students' experiences regarding reflection, especially the educator's role in motivating student engagement, other than using marks as an incentive, based on an assumption that assessment will drive learning (Sandars 2009). Reflection is usually an individual activity. Mackintosh $(1998,556)$ warns about the "emphasis on individual perspectives of events, their interpretation and their analysis, [which] excludes all other viewpoints: those of the multidisciplinary team and, most importantly, the client group, patients or carers." While group reflections do occur when students work together collectively to produce reflective reports, the group effort can limit the value of the reflective process and potential learning from it (Rogers 2001 referring to Seibert and Daudelin 1999). The sharing of each student's individual reflection with their peers (in a shared space) seems to be a less explored option, although Wear et al. (2012) have reported on the scope of collective engagement for constructing new meanings among a community of students.

This paper addresses the question of how it might be possible to facilitate reflective practice as a socially just pedagogical practice. How can reflections be valued/able tools for students immersed in practical learning within a context where unjust practices prevail? In order to address this question, I consider, first, teaching and learning through and from reflective practices as processes and products, pointing out the numerous challenges in this regard. Second, I propose an expanded perspective that can offer more possibilities 
for promoting social justice through the generative potential of diffracting reflective texts. The theoretical concepts of new materialism provide a refreshing perspective for taking reflection further. This emerging field of study recognises that individuals are not separate entities but, rather, enactments with/through the in/determinate entangled relationships between different humans, non-humans and material forces (Barad 2007). While an increasing number of studies relate to diffractive methodologies in research (Bozalek and Zembylas 2016; Lenz Taguchi and Palmer 2013; MacLure 2013; Ringrose and Renold 2014; Sellers 2013), using diffraction in a practical way with students in higher education appears to be relatively unexplored. In the third section of the paper, I show how diffraction has empowered students to become agents of change. The openly shared reflective apparatuses create potentials for transformative and productive relationships where matter and meaning are not separated but "mutually articulated" in dynamic material-discursive relationships (Barad 2007, 152). In her seminal book, Meeting the Universe Halfway, Barad $(2007,148)$ explains that "apparatuses are the material conditions of possibility and impossibility of mattering; they enact what matters and what is excluded from mattering."

A socially just pedagogy offers a hopeful pathway for exploring such possibilities. It is conceived as a becoming rather than being: that which opens up "spaces of resistance [and] conditions for social justice" (Goodley 2007, 323). According to Moje $(2007,4)$, it creates a space and place where intellectual and moral issues can be fused to teach with and for social justice, with a transformative potential to "provide opportunities to question, challenge, and reconstruct knowledge." Chubbuck and Zembylas $(2008,310)$ point out that "the emotional intensity of engaging in socially just teaching is not entirely safe but is full of ambivalence." Where injustices exist and persist, curricular tasks need to enable students to shift beyond positions of silenced compliance, a response that is unlikely to effect change. Below I discuss traditional reflective practices, then move on to thinking and working with/through these ideas to a diffractive methodology, explaining how it is enacted in the context of obstetrics learning where there is a prevalence of unjust practices witnessed by undergraduate medical students (Vivian et al. 2011). These concerning and persistent injustices are experienced by many women giving birth in public health facilities in South Africa. Patients" "narratives of distress" have been documented by Chadwick, Cooper and Harries (2014), as well as the Human Rights Watch (Odhiambo 2011).

\section{REFLECTIVE PRACTICES}

Reflective practice is difficult to define. Different terms are used such as reflective, reflection, critical reflection and reflexivity, with each denoting different aspects of self-examination (Bozalek and Zembylas 2016). Roger's (2001) detailed conceptual analysis of reflective practices in higher education indicates 15 different terms. Further confusion arises in the teaching process because reflection is sometimes used as a verb 
and other times as a noun, an adjective, or a way of describing a process or a purposeful outcome (Rogers 2001). This ambiguity can limit advancement and improvement for teaching practices (Kreber 2004) and the transformative potential of reflection.

But even with so much uncertainty, there are relatively few publications related to reflective tasks with undergraduate medical students (Grant et al. 2006). The AMEE Education Guide (Sandars 2009), produced by the International Association for Medical Education, indicates how reflection can be used more effectively in medical education. However, Sandars $(2009,689)$ acknowledges that as far as students are concerned, there "have been no longitudinal studies during the medical school experience and there is no evidence of the benefits of reflection on their long-term development, especially in their subsequent clinical care." Later, Aronson (2011, 200-201) refers to Mezirow's (1990) definition of critical reflection by describing it as "the process of analyzing, questioning, and reframing an experience in order to make an assessment of it for the purposes of learning (reflective learning) and/or to improve practice (reflective practice)." She offers 12 tips for medical educators to effectively teach reflection, including reflecting on their own teaching. These tips indicate a top-down contained approach in terms of pedagogical design, implementation and evaluation interpreted through the educators' interests and perceptions about students' needs to advance learning. I contend that more openness related to and directed by/with the students can be more beneficial.

The skills developed in reflective practices in medicine aim to promote students' clinical reasoning (Murphy 2004) and problem-solving skills (Mamede, Schmidt and Penaforte 2008), as well as boost their confidence for work integration, help them gain a better understanding of their own learning styles and, with support from others, help them identify knowledge gaps (Grant et al. 2006). Such epistemological, individualistic insights for developing competence tend to exclude contextual and relational issues that can be more challenging.

\section{LOOKING BACK ON REFLECTIVE PRACTICE: PROCESS AND PRODUCT}

To explore how reflective practices can become more expansive, beyond issues of individual competence, I examine present processes and outcomes of students' reflective tasks. I then suggest a turn to diffraction, explaining how this open, relational process can move beyond the apparent problems of reflective practices to become more appropriate for socially just pedagogies. My own interest in reflection began when I started to question whether any value was gained by students from their prescriptive curricular reflective activities. The catalyst was an explanation of strategic fabrication by a group of first year students who admitted to deviating from the truth to comply with the task criteria so as to successfully achieve the course directives. This concerned me as the product was undermining the process. "Processually speaking, a making is always bigger than the made" (Massumi in Manning 2012, xi). The initial quote in this paper 
arises from a fourth year undergraduate medical student at UCT who refers to the habits and attitudes developed in the early years of training that continue to influence students like him in their being and becoming in terms of their present/future studies and careers, as well as their wider engagement with others. Such criticisms and unwillingness to engage in the process are not uncommon (Song and Stewart 2012).

The iterative reflective process of self-examination and self-regulation aims to encourage personal and professional development. To guide this introspection, a variety of models are used (Butler 1996; Gibbs 1988; Johns 2000; Kolb 1984; Rolfe, Freshwater and Jasper 2001). Boud, Keogh and Walker $(1985,19)$ proclaim that "[i]t is only when we bring our ideas to our consciousness that we can evaluate them and begin to make choices about what we will and will not do." This is facilitated through different approaches, such as inner dialogue and prompts through probing questions (Biggs and Tang 2007; Gibbs 1988). Hatton and Smith (1995) offer an emancipatory model that examines experiences in relation to political, economic and cultural influences - a move towards a socially just pedagogy that acknowledges multiple perspectives within the wider context of an event. For instance, a student may not wish to be critical about an educator's practice because cultural beliefs demand respect for elders and those who hold positions of authority.

Critical incidents and personal narratives are frequently used to trigger reflections in curricular tasks, though often clouded with personal and ethical dilemmas. For instance, is the curriculum asking students to report unsettling incidents that can reveal their vulnerability and sense of powerlessness, or does it encourage students to contain their reflections as "glowing" accounts of how they imagined practice to be? As I question what the curricular tasks are doing these concepts are taken further beyond a humanist perspective through new materialism, where matter matters, and where more can be gained towards reaching socially just practices. Barad $(2010,242)$ claims that,

Science and justice, matter and meaning are not separate elements that intersect now and again. They are inextricably fused together, and no event, no matter how energetic, can tear them asunder. They cannot be dissociated.

\section{REFLECTION OUTCOMES AS PRODUCT}

In higher education, the reflective product is a central focus, usually for the purpose of student assessment. Resonating with my students' practices, Boud (1999), Hargreaves (2004) and Rai (2006) question the truthfulness and integrity of reflections, admitting that "we may have inadvertently taught our students to suppress, rather than critique and examine their thoughts and feelings" (Hargreaves 2004, 200). This is particularly true when reflections are awarded marks. Assessments measure competence and skills that discourage students to use the opportunity to acknowledge their self-limitations, especially in a competitive, judgmental and critical environment like the health 
sciences. As my students' feedback indicates, they may feel pressurised to be strategic in producing what they anticipate the educators want to read (McMullan 2006; Moon 2001).

Critical reflection that indicates transformed meaning perspectives (Mezirow 1990) can be unhelpful, even problematic (Massumi 2002). Brian Massumi $(2002,220)$ explains that a critical practice "separates something out, attributes set characteristics to it, then applies a final judgment to it - objectifies it, in a moralising kind of way." According to Barad (in an interview with Juelskjaer and Schwennesen [2012, 14]), criticism "enacts a linear temporality that closes down rather than opens up what is to come," a process that she claims causes "epistemic damage" and is, therefore, unhelpful. Instead, she encourages us to work through different thought patterns. Moving from an individual viewpoint towards the wider context, Zembylas (2013) refers to critical emotional reflexivity as a starting point for students to re-establish their beliefs, thoughts and habits in light of their experiences. The concept of diffraction, explained later in this paper, enables us to go further, beyond such issues of individualist subjectivity.

Critique is different but also problematic. It introduces negativity, often pitting one viewpoint against another in a reductionist manner (Bozalek and Zembylas 2016). However, it does have an important role if taken up with an affirmative approach that Braidotti (2006) claims as more ethical as it can then elicit a vitality and affective intensity. Referring to Spinoza, Deleuze describes affect as the body's capacity to affect and to be affected, like a charge that provides energy and movement (Massumi in Deleuze and Guattari 1987). Affect is integral to reflective practice, yet it tends not to be acknowledged, especially when only the product of reflection is considered, as in summative assessment practices. Massumi $(2002,12)$ explains that "[w]hen you affect something, you are at the same time opening yourself up to being affected in turn, and in a slightly different way than you might have been the moment before." When reflections are considered as merely technical tasks to be handed in to adhere to course requirements, the assumed closure limits affect and the intensities that can possibly emerge. For instance, affect can be a key component in triggering a sense of activism within a student group who recognise a need for change to the established and normalised unjust practices that they have observed during their clinical rotation.

\section{IN MEDICINE}

Medicine has a history of positivist linear perspectives that focus on single paradigms rather than multiplicities and uncertainties (Kneebone 2002). Teaching medical students to be self-reflective forms part of a global shift for training in the health sciences, yet engagement with the context in which reflection takes place is the most seriously underdeveloped consideration in the use of reflection in higher education (Boud 1999). Bleakley (1999, 323), developing Schön's (1987) notion of reflection in and on action, argues for "reflection-as-action" where the "locus for reflection" is contextually situated 
within the total event rather than in the individual, framing it with sensitivity to the being of the individual rather than the doing towards developing socially responsive practitioners. This move towards the process of becoming within a broader context is important and aligns with the need for graduates to engage with transformative learning, to become socially responsive change agents in the healthcare professions (Hartman et al. 2012). Barad (2007) explains that our entangled relationships create the process of becoming-with the other.

However, the ubiquitous inclusion of reflections in many clinical and preclinical courses has led to reflection becoming institutionalised and routinely instrumentalised as a task that needs doing which has, in many instances, led to it losing its meaningfulness and becoming counter-productive, as indicated earlier. It represents practices in a reproductive or critical manner without the opportunity to take suggestions further. Instead of promoting change, such re-presentational practices re/produce sameness that is reductive and actually unhelpful. Braidotti (2006) points out that representations of others can be oppressive, even abusive. A growing "post" movement of new feminist materialist theorists (Davies et al. 2013; MacLure 2013; Sellers 2013; Vannini 2015) claim that working with non-representational thinking is more useful to create possibilities for the emergence of novel potentials. This fluid and more dynamic process suggests an opening up to ethical questioning on "how things come to matter in the ways they do" (Davies et al. 2013, 680). In terms of non-representational thinking the flow is not necessarily structured or certain. To produce something new rather than to replicate sameness, there needs to be experimentation and the materialisation of an indeterminacy that can move beyond pre-defined structures and boundaries (Barad 2007). Such new thinking can shift curricular design away from technical, linear and static processes (Lenz Taguchi 2010). Vannini $(2015,12)$ claims that "[i]t is no longer what happened that matters so much but rather what is happening now and what can happen next." Rather than maintaining a distance in an objective and critical manner as separated entities, students need to become immersed in affirmative affective fields emerging from their learning events, to be "part of the world in its ongoing intra-activity" rather than standing outside of it as occurs in traditional representational thinking (Barad 2007, 146).

Reflections are frequently used as an add-on to other curricular tasks, as illustrated by the student's opening quote. Rather than separations, we ought to make connections and commitments (Barad 2014) as separations and detachments, apart from being unhelpful, can also possibly be unethical in that they actually encourage students to falsify their thoughts and feelings. Barad (2007) claims that epistemology and ontology are entangled with ethics in an inseparable manner that she terms an ethico-ontoepistemology. New knowledge is elicited through the entwining of ethics with our beings and available knowledge. Such a relational ontology indicates how cause and effect are not linear binary progressions that occur through dyadic relations, but are, 
rather, enmeshed in a complex web of relations. There is a queering of causality in/ through events. Barad $(2012,46-7)$ contends that,

Accountability cannot be reduced to identifying individual causal factors and assigning blame to this or that cause. Indeed, causality is an altogether queer matter. Rather, accountability is an ethico-onto-epistemological commitment to understand how different cuts matter in the reiterative intra-activity of worlding.

The concept of worlding refers to our entanglement in a collective world, where relationships occur and are made between humans and "the other than human" (Barad 2007, 392). It encapsulates a wider range of possibilities and agential forces than the limitations imposed by a humanistic viewpoint. Within this broader scope, Barad's (2007) concept of agential realism explains how within these worldly relationships, cuts are agentially enacted, thereby indicating what matters and what gets excluded. Barad $(2007,178)$ puts forward that

Particular possibilities for (intra-)acting exist at every moment, and these changing possibilities entail an ethical obligation to intra-act responsibly in the world's becoming, to contest and rework what matters and what is excluded from mattering.

In each event and experience, there is a relating of agencies that constitutes the iterative enactments of the encounter. Ethics and student responsibilities are not separate issues but are rather entangled in their becoming-with other agential forces. In my search to make reflections matter, more meaningful for students and possibly transformative, particularly around issues of social justice and change, these relationships became more pertinent. Wear et al. $(2012,605)$ suggest that,

Through transformative action, reflective practices can move beyond a cul-de-sac of selfcongratulation for engaging in the reflective process to a recognition of the need for ethical action - taking a risk, redressing a wrong, or, at the very least, resolving to do things differently the next time.

For reflective practices to become socially just pedagogies, educational spaces are needed where students can feel comfortable grappling with their thoughts and experiences (Slater 2012) and move beyond the privacy of individual subjectivity to interrelationships that matter. According to Moje $(2007,4)$, there ought to be "possibilities for transformation not only of the learner but also of the social and political contexts." Below I propose diffraction as a tool for facilitating this change.

\section{DIFFRACTION OF STUDENTS' EXPERIENCES}

How can reflective practices matter and become more valued tools for socially just pedagogies? Barad $(2007,149)$ asserts that "knowing is a matter of differential responsiveness ... to what matters." Students' feedback comments as quoted below indicate how much they appreciate the process of opening up their thinking to/with 
others. I propose that we should move beyond an individual humanist approach by acknowledging the relationships of non-human forces. Theoretical concepts of new materialism offer insights that engage with the more-than-human, with the multitude of relationships and how they matter, and which determine our becoming. Intra-actions are formed in these on-going relationships between humans and non-humans as they affect and are affected by each other through their mutuality and their agential forces (Barad 2007). Intra-action is an all-inclusive enactment that emerges as a consequence of the mutual relationships in/between humans, non-humans and matter. It is more expansive than interaction which describes a humanist event that happens between individual people or within a collective group in their engagement with each other and is comparatively limiting and reductive. Intra-activities involve subtle and complex forces that are fluid, dynamic and mutually constituted between human and non-human forces (Barad 2007). Rather than matter observed at a distance as static and passive, in/through new materialism there is a materialising agency. It is "an enactment, not something that someone or something has" (Barad 2007, 235). There is involvement rather than separation where movements occur with/in thinking (Sellers 2013).

When considering students' reflective commentaries, a new perspective that acknowledges the materiality of the text allows us to recognise the multiple relationships that intra-act to generate and produce the text. There are intra-activities between computer screens, keyboards, fingers, students' thoughts and ideas, and their experiences. (A similar dynamic apparatus is working with/through me in co-constituting the production of this paper). This spreading of forces and intensities in multiple ways and patterns demonstrates diffractive thinking and working. Sellers $(2013,19)$ offers a helpful explanation about the affect/effect of her keyboard.

In some mo(ve)ments I become lost in space-times of a messy middle-muddle of the territory ... Diffraction unfolds the idea that, where different bodies meet, it is what happens in-between that matters for their ongoing engagement. It is relations on intra-activity in-between that intensify understandings rather than simply reflecting on the interactions that occur between separate bodies.

The term diffraction means to "break apart in different directions" (Barad 2007, 168) and is derived from the Latin verb "diffringere" - dis (apart) and frangere (break). Unlike reflection that refers to our own positioning as pre-existing individuals, and which draws us back into ourselves as knowing subjects, diffraction is a dynamic, entangled process that enacts newness. It involves differences-in-the-making. Haraway $(2000,102)$, who initiated the philosophical concept of diffraction as an optical metaphor, points out that "diffraction patterns record the history of interaction, interference, reinforcement, difference."

Diffraction generates new opportunities for teaching, learning and educational change by opening up the traditional boundaries of reflective commentaries between students and educators, and by moving from private to public communication where more interferences can be brought about. "Each bit of matter, each moment of time, 
each position in space is a multiplicity" (Barad 2014, 176). Diffraction requires us to "read insights through one another in attending to and responding to the details and specifications of relations of difference and how they matter" (Barad 2007, 71), thus enabling transformation to occur in the in-between spaces - a democratic practice.

When considering student learning, intra-actions and the related intra-activities bring novel insights. For instance, in text-based reflective commentaries, the materiality of non-human forces plays an important contribution that is missed through an anthropocentric gaze. The reflective texts have a force and agency that materialises with/through other forces. Rather than re/producing the binary of subject/student and object/text, relations emerge in the in-between spaces where students becoming-doctors are enmeshed.

If reflective texts can be diffracted with/through each other, like waves interfering with each other in the ocean, a new in-between space is opened up, like new patterns that are formed in/through the water. Palmer $(2011,8)$ explains this as a "wave-like motion that takes into account that thinking, seeing and knowing are never done in isolation but are always affected by different material and human forces coming together." As Bozalek and Zembylas $(2016,123)$ have indicated in their paper on research methodologies, diffraction offers "an enlarged vision of making a difference in the world" as it "provides additional affordances through its connection of the discursive and the material, with knowledges making themselves intelligible to each other in creative and unpredictable ways." Diffraction can expand reflective practice in a horizontal way, enabling the agency of different reflective texts to interfere with each other and, in so doing, to make a difference. Using the case study below, I suggest that diffraction of reflective texts adds a fruitful and productive force, like the crests of waves connecting to amplify each other. It is also an inclusive process that provides an ethical tool to incorporate multiple perspectives by reading insights through each other, avoiding damage caused by critical and judgmental thinking, and by giving "care-full" consideration to texts (Barad in Juelskjaer and Schwennesen 2012). The multiplicities make visible the "superposition of beings, becomings, here and there's, now and then's" (Barad 2014, 176), like the crests of waves meeting and then becoming amplified, a superposition of the new. There is a focus on relationships to illuminate these interference patterns, rather than on individualist subjectivities and identities. According to Kaiser and Thiele $(2014,166)$, diffraction offers an "openness to affirmative-critical devices that disrupt, intervene and cut-together-apart (diffract) meaning-mattering processes," and can therefore be used as a teaching mechanism for change. Diffraction explores patterns that can open up a transformative process, enabling students to collectively engage with the social and political contestations they confront through their curricular encounters. It can attend to matters of justice and injustice.

In what follows, I describe how online collective engagement is enabling a diffractive methodology and making a difference through the emerging materialdiscursive relationships that take students' reflections beyond traditional practices. 


\section{IN PRACTICE}

Case study: How can we explicate a diffractive methodology to effect change?

Below I refer to findings from my ethics approved $\mathrm{PhD}$ research project in which I have allowed myself to be receptive to special moments and events that have "glowed" for me, ${ }^{1}$ data that has "invited [me] in" (MacLure 2013, 662). The influence of affect with its forces and potentials has pulled and tugged on me, taking up an increasingly greater part of the focus of this study. As I follow the flows of non-representational thinking, I seek out potentials and possibilities in the movements and rhythms of what comes to matter.

I move on to explain how reflective practices have developed iteratively into diffractive open processes that are making a difference. Below I describe the intraactions that iteratively developed in my facilitation of health and human rights workshops in the Department of Obstetrics and Gynaecology at UCT. Annually five groups of approximately 45 medical students move through their eight-week obstetrics block at different times of the year.

\section{THE SETTING}

Fourth year medical undergraduate students walk into birthing facilities often anxious and nervous, some terrified as they consider their new responsibilities in practical obstetrics. There are beds, plastic aprons, packs with gloves and scissors, foetal monitoring machines, sluice rooms, fridges and other matter positioned aside and beyond. There are humans, some screaming in pain before and during the birthing process, others shouting with frustration. At times these health professionals may blame an "unco-operative" mum-to-be with phrases such as "you're killing your baby." A few fortunate students are taken on an orientation walkabout while the majority are thrown into the turmoil, at times jumping into action, stretching, leaning or just grabbing a neonate to avoid a harsh arrival falling to the floor.

Many students witness harmful, unjust practices, especially in cases involving teenagers and foreign nationals. Scissors are used to cut women, without warning, and often without analgaesics. Students look on, shocked, sensitive to their helplessness. A student noted "feeling useless ... frozen in place," with "thoughts of disgust towards the nurse ... as our bodies became part of the surroundings." A student realises that "the ideas and principles of do no harm only applied to physical health, and seldom extended to the emotional and mental wellbeings [sic] of patients. Delivery rooms were often cold and sterile and mothers were [often] forced to endure childbirth alone."

1 Maggie MacLure $(2013,661)$ recommends that researchers move beyond static, coded, themed approaches to post-qualitative research, towards "the emergence of sense in encounters with data" through and with the "hotpsots" of data that appear to "glow." 

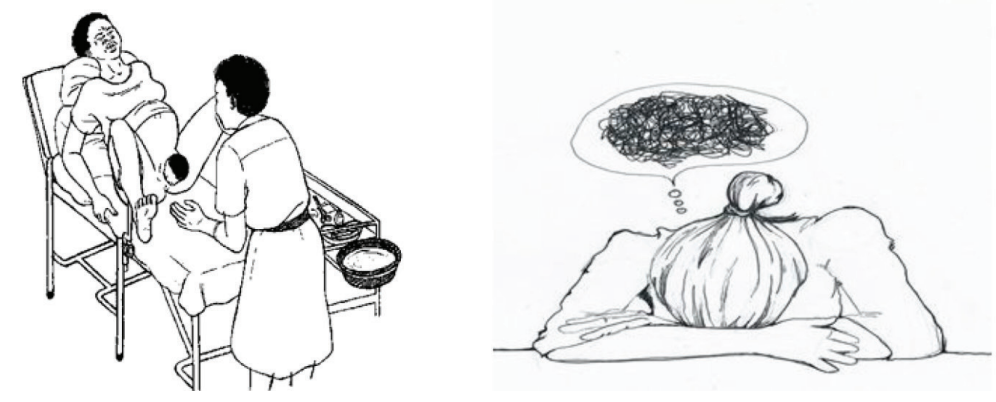

Figure 1 and Figure 2: Drawings in reflective commentary by Naledi Nkabinde, fourth year medical student at UCT

In my role as a facilitator of student learning, I felt emotionally drained by reading and listening to the collective narratives of students' experiences as described above. How could their reflections contribute to changing practices rather than stay bounded simply as curricular tasks for hand-in?

My experiences with marking reflective commentaries in the earlier curricular years had left me questioning their validity and purpose, asking what were the reflective tasks doing for the students and their learning? During classroom engagement with senior students in their fourth year, feedback on a Google Doc about their earlier curricular reflective activities confirmed my concerns as they indicated boredom with the process and concerns about the purpose as it "seemed forced and artificial," as well as tedious and a waste of their precious time. The repetitive, formulaic method used appeared to give the impression of superficiality, similar to following a recipe book, a concern noted by Boud (1999) which resulted in reflections without learning. Many students recalled doing their reflective tasks at the last minute, and merely for the purposes of getting the job done and ticking off the course requirements, rather than as a meaningful task for future practice. A few students expressed appreciation, gaining new and deep insights from the process.

Yet, as indicated by my text above, students immersed in their eight-week obstetrics training frequently witness physical, emotional and verbal abuse directed at women in labour (Vivian et al. 2011). Expressions of guilt, shame and regret at staying silent and passive indicate how many students feel disempowered by the curricular arrangements, medical hierarchy and other influences. As a result, I found myself reworking and experimenting with reflective practices which led to a new visual framework (Figure 3), the Six Step Spiral for Critical Reflexivity (SSS4CR), adapted from Gibb's (1998) model of reflection. Over the past five years, students have used it to reflect and report on their encounters in the public birthing facilities. 


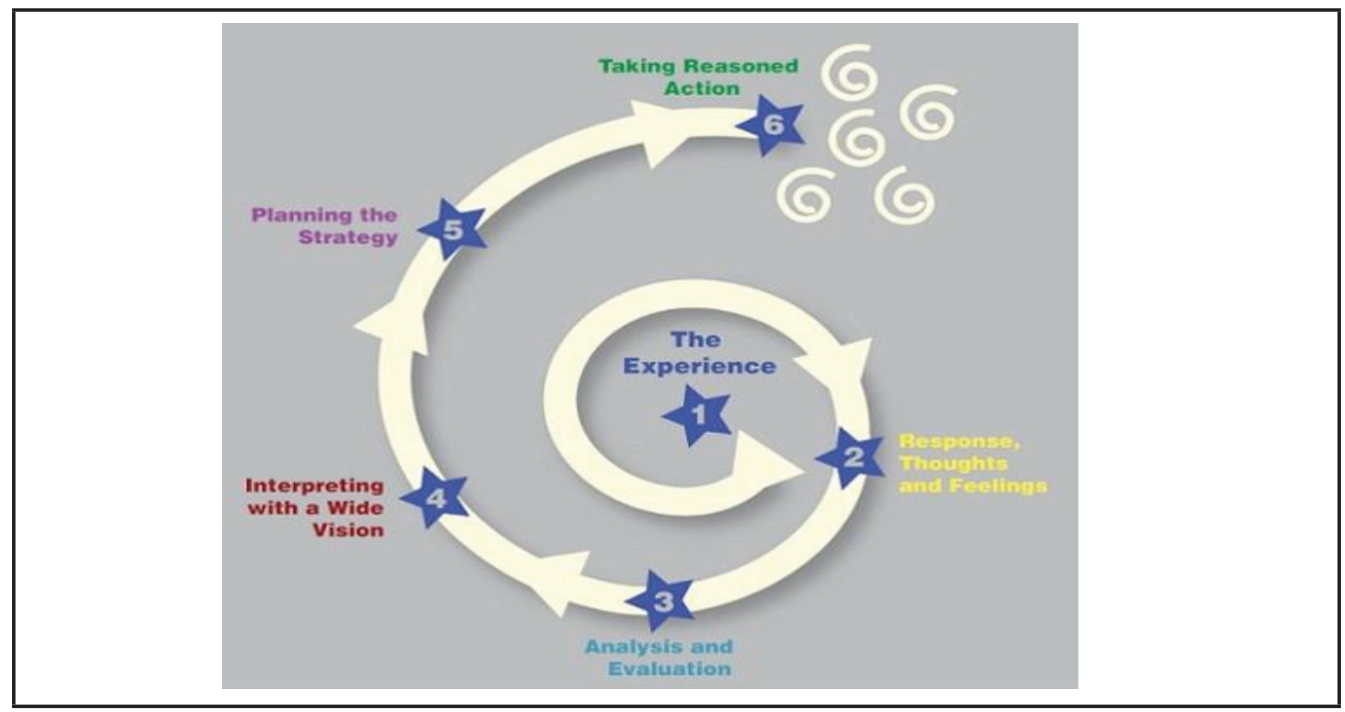

Figure 3: Six Step Spiral for Critical Reflexivity (SSS4CR)

Positive feedback on the SSS4CR indicated how students' relationships with wider influences became clearer as they unpacked their events through multiple perspectives. Most striking was that many students expressed appreciation for reading/hearing about the experiences of their colleagues. This awareness from self to the collective gave impetus to an opening up process, moving beyond individual unease, at times trauma, to a collective recognition for a need to change the normalised structural injustices that pervade practices in our healthcare system.

A major breakthrough was the change to online sharing using the affordances of Google Drive, a cloud-based platform. I was able to facilitate a space for a collaborative surfacing of students' encounters in obstetrics. The intra-active materiality and agency of Google Docs expanded possibilities for mapping different experiences and insights, producing deeper thought and dialogue across the previously bounded reflective process. The intensity of the intra-actions contributed to the impact of the practice more than traditional bounded interactions. A student's feedback noted, "[the process] has made me realise what is acceptable, and what is not, and how repetition causes people to become numb to patient's feelings." In the online intra-actions, a circulation of affect was apparent, offering the potential for students to act in different ways with a sense of empowerment to become advocates for women's rights. This appeared to be a more ethical approach for reflective practice than simple hand-ins to comply with curricular needs.

Comments from students' feedback on sharing their reflective commentaries included: 
"To know that I'm not alone in my feelings, and that it's not a weakness to be sensitive to these situations." This student felt that his/her emotions were normalised, a move beyond the personal to a collective sense of solidarity.

"I just wanted to share my experience with the others because someday they might experience the same thing." This student's event becomes a learning platform for others in order to build their confidence in promoting justice rather than feeling shocked and disempowered. Another student expanded on this affirmative aspect saying, "it will help them come up with a plan of action if ever placed in a similar situation."

"Realising that there is a lot of bad health care practice going on in our hospitals. And it goes unaddressed." Here the student recognised the wider political issues that were not initially evident, so that $\mathrm{s} / \mathrm{he}$ is now able to question his/her role in a weak healthcare system.

"Being able to see how much bad practice has been experienced ... and noting that even though we are students we can still make a difference by initiating that empathic practice." This student, like many others, appeared to move from a position of vulnerability to one of power with an urgency to make a difference.

The online platform provides an educational space for students to "grow a new type of knowledge that is transformative and praxis oriented" (Zembylas 2013, 12). Students indicated the value of reading each other's reflective texts. However, no-one was willing to comment on the text of their peers, despite my encouragement. Once the text is produced, there seems to be a separation of text from student, a completed task that becomes closed. Perhaps once texts are put out on the Google platform, students disconnect themselves from it. There may also be a sense of vulnerability if they engage with their peers' personal experiences through texts.

Students work from a humanist, autonomous perspective without recognition of the force of the text and the dynamic apparatus that carries potential. My plan for future engagement is to encourage this extension of commenting on each other's experiences, to embrace the diffractive process that appears to be an untapped potential.

Opening up multiple texts that can work together and apart adds opportunities for new possibilities, as well as vitality and intensities that can then produce change, particularly related to the injustices witnessed by students in their learning contexts. This process reconnects "affectively to the collective in a different way, moving away from thinking about 'being active' in the sense of 'doing something' and focusing instead on the in-act of 'something doing'" (Massumi 2015, 165).

Beyond the class group intra-actions, the reflective texts have diffracted further by spreading out through many connections that have led to interrelated actions. In the classroom, roleplays depict a few of the shared scenarios. Now in the department, previously silenced students' experiences are amplified for engagement on the issues extending further outwards to facilities and the metropolitan health department. In one instance, students joined a disciplinary hearing relating to an incident that they had observed. 


\section{LIMITATIONS}

This paper highlights how problematic reflective practices are for many students and educators. Sharing their reflections online is not taken up by all students. The number of contributions uploaded varies with each set of students - a pattern that students explain with reference to the timing of their learning rotation or their own prioritisation of their curricular tasks. Furthermore, some students feel vulnerable sharing. The first block of students, at the start of the academic year, tend to be keener to share their contributions than those whose turn comes later, when work pressures from other disciplines have led to higher stress levels. As mentioned earlier, some students are driven by assessment needs, so they hand in hard copies of their reflective commentaries solely to adhere to the curricular performance requirements. Uploading commentaries online is an extra process that can be avoided, especially if not related to marks. Some students note that they just "don't get there" due to their overloaded curriculum.

In terms of disruptive events, Massumi $(2015,124)$ points out a "double becoming," in which there are risks being taken "with who you think and feel you are and what you can become." This concept introduced by Deleuze and Guattari (1987) refers to major and minor variables that coexist and change asymmetrically in the process of simultaneously becoming. In this study, becoming vulnerable for students can be considered as the minor variable entwined in the major institutional variables.

Feedback from students indicates that many are unwilling to take the risk of sharing their personal thoughts and to expose their vulnerabilities, sensing an invasion of their privacy through self-disclosure (McMullan 2006). Zembylas (2012) refers to emotional labour when working with discomfort, suggesting that these troubling moments are challenging yet can be provocative moves to problematise injustices. These students frequently choose to remain anonymous. I offer to upload their commentary against a posting number rather than a name.

For students to have the courage to speak or write with honesty about their difficult experiences, they need a degree of fearlessness. Wear et al. (2011) refer to the Greek word, "parrhesia" (meaning to speak freely) as a desired approach to confront the power and political arrangements that frequently "numb" students. In the case of obstetrics abuse, students recognise their vulnerabilities within the established medical hierarchical arrangements where power differentials deter efforts to expose themselves as observers of poor practices. By their fourth year, students have learnt the institutional culture and adapted to it. Boud, Keogh and Walker $(1985,39)$ assert that "[i]f professionals are to develop skills in reflective thinking it is important that they be encouraged to do so in their initial training."

Some students read the commentaries of others that have been placed online, yet do not contribute their own. This may be considered unfair, however it does offer an opportunity for the iterative emergence of a new sense of response-ability (Barad 2007).

This case study in obstetrics refers to an eight-week course at one institution and a related research project. The reflective process is limited by the established practices 
set up in previous years that tend to be linear, individualistic and contained with limited meaningfulness for most students as indicated by the opening quotation. Massumi (2015, 147) uses the term immediation to describe the continuum of affective movements as "the past [is] bumping against the future in the present." Students' learning experiences continue to stay with them, influencing their becoming.

Facilitating the diffraction of students' reflections can be a valuable pedagogical practice for other disciplines and health science faculties, particularly in South Africa as it provides an affirmative opportunity for students and educators to engage meaningfully with multiple perspectives within a diverse student group, and it offers a tool for "staying with the trouble" (Haraway 2016) rather than avoiding and silencing it. The increasing affordances of online platforms enable this kind of sharing. As observed, attentive facilitation is necessary to ensure care/full respect for all (Barad 2007).

\section{CONCLUSION}

Diffractive readings bring inventive provocations; they are good to think with. They are respectful, detailed, ethical. (Barad in Dolphijn and van der Tuin 2012, 50)

In this paper, I explain the prevalence of reflective practice in professional disciplines with a focus on medical education. The purposes of including reflection in curricula is explored leading to an explanation of approaches that focus on the process and/or the product, also explaining their difficulties for both educators and students.

Using Barad's diffractive methodology, I describe how the sameness and distancing involved in reflective practices can be expanded by thinking and working through diffraction where the agential forces of human and non-humans are entangled and, through their interferences, produce new knowledge. Using students' experiences in obstetrics, my case study illustrates how students' reflective commentaries can be juxtaposed on a Google folder to open up traditional boundaries of contained reflections and to elicit an affective intensity through the sharing. Taking an affirmative focus on differences, there is a move away from critique and critical humanist perspectives. Diffraction takes reflective practices beyond the private realm and the binaries of student/educator, theory/practice, experience/writing. New possibilities are invoked towards responding to social injustices (such as abusive practices in birthing facilities), thereby empowering and motivating students to become change makers.

A new materialism perspective offers insights that provide innovative ways of exploring students' clinical encounters. This expanded view of unpacking students' actions and inactions offers hope and possibilities to facilitate a process of change. As Barad notes:

What if it is only in facing the "inhuman"- the indeterminate non/being of mattering and not mattering - that an ethics committed to the rupture of indifference can arise? What if it is only in the encounter with the inhuman, in its liveliness, in its gifting life and death its conditions 
of im/possibility, that we can truly confront "our" inhumanity, that is, "our" actions lacking compassion? Perhaps it takes facing the inhuman within "us" before compassion-suffering together with, participating with, feeling with, being moved by - can be lived. How would we feel if it is by way of the inhuman that we come to feel, to care, to respond? (Barad in Kleinman 2012,81)

Exciting prospects are anticipated in using diffraction as a novel pedagogical practice. This is the start of more to come as each diffraction creates new potentials.

\section{ACKNOWLEDGEMENTS}

Special thanks to Naledi Nkabinde. Her reflective text and images have transformed an "horrific event" to a tool for social change. I wish to acknowledge Professor Wendy McMillan who guided my diffractive thoughts beyond the obstacles that confronted me. Her presence continues to be with me. Thank you to Professor Vivienne Bozalek for opportunities and inspiration to diffract my own reflections. This research project is funded by the South African National Research Foundation, Grant no. 86370.

\section{NOTE}

1. Student quotes in this article arise from workshops in 2015 and 2016 and a research interview in 2015 .

\section{REFERENCES}

Argyris, C., and D. Schön. 1974. Theories in Practice: Increasing professional effectiveness. San Francisco: Jossey-Bass.

Aronson, L. 2011. "Twelve Tips for Teaching Reflection at All Levels of Medical Education." Medical Teacher 33 (3): 200-205. https://doi.org/10.3109/0142159X.2010.507714

Barad, K. 2007. Meeting the Universe Halfway: Quantum Physics and the Entanglement of Matter and Meaning. Durham: Duke University Press. https://doi.org/10.1215/9780822388128

Barad, K. 2010. "Quantum Entanglements and Hauntological Relations of Inheritance: Dis/Continuities, SpaceTime Enfoldings, and Justice-to-Come.” Derrida Today 3 (2): 240-68. https://doi.org/10.3366/ drt.2010.0206

Barad, K. 2012. "Nature's Queer Performativity.” Kvinder, Køn og Forskning/Women, Gender and Research $1(2): 25-53$. 
Barad, K. 2014. "Diffracting Diffraction: Cutting Together-Apart." Parallax 20 (3): 168-87. https://doi.or g/10.1080/13534645.2014.927623

Biggs, J., and C. Tang. 2007. Teaching for Quality Learning at University. 3rd ed. Berkshire: Open University Press and McGraw-Hill.

Bleakley, A. 1999. "From Reflective Practice to Holistic Reflexivity." Studies in Higher Education 24 (3): 315-30. https://doi.org/10.1080/03075079912331379925

Boud, D. 1999. "Avoiding the Traps: Seeking Good Practice in the Use of Self Assessment and Reflection in Professional Courses." Social Work Education 18 (2): 121-32. https://doi. org/10.1080/02615479911220131

Boud, D. 2001. "Using Journal Writing to Enhance Reflective Practice." New Directions for Adult and Continuing Education 90: 9-18. 16 https://doi.org/10.1002/ace.16

Boud, D., R. Keogh, and D. Walker. 1985. Reflection: Turning Experience into Learning. London: Kogan Press.

Boud, D., and D. Walker. 1998. "Promoting Reflection in Professional Courses: The Challenge of Context." Studies in Higher Education 23 (2): 191-206. https://doi.org/10.1080/03075079812331380384

Bozalek, V., and M. Zembylas. 2016. "Diffraction or Reflection? Sketching the Contours of Two Methodologies in Educational Research.” International Journal of Qualitative Studies in Education 30 (2): 111-27. https://doi.org/10.1080/09518398.2016.1201166

Braidotti, R. 2006. Transpositions: On Nomadic Ethics. Cambridge: Polity Press.

Brookfield, S. 1995. Becoming a Critically Reflective Teacher. San Francisco: Jossey-Bass.

Butler, J. 1996. "Professional Development: Practice as Text, Reflection as Process, and Self as Locus." Australian Journal of Education 40 (3): 265-83. https://doi.org/10.1177/000494419604000305

Chadwick, R. J., D. Cooper, and J. Harries. 2014. "Narratives of Distress about Birth in South African Public Maternity Settings: A Qualitative Study." Midwifery 30 (7): 862-58. https://doi.org/10.1016/j. midw.2013.12.014

Chubbuck, S. M., and M. Zembylas. 2008. "The Emotional Ambivalence of Socially Just Teaching: A Case Study of a Novice Urban Schoolteacher." American Educational Research Journal 45 (2): 274-318. https://doi.org/10.3102/0002831207311586

Davies, B., E. De Schauwer, L. Claes, K. De Munck, I. Van De Putte, and M. Verstichele. 2013. "Recognition and Difference: A Collective Biography." International Journal of Qualitative Studies in Education 26 (6): 680-91. https://doi.org/10.1080/09518398.2013.788757

Deleuze, G., and F. Guattari. 1987. A Thousand Plateaus: Capitalism and Schizophrenia. Translated by B. Massumi. Minneapolis: University of Minnesota Press.

Dolphijn, R., and I. van der Tuin. 2012. New Materialism: Interviews and Cartographies. Michigan: Open Humanities Press. https://doi.org/10.3998/ohp.11515701.0001.001 
Dewey, J. 1938. Experience and Education. New York: Simon and Schuster.

Fook, J., and F. Gardner. 2007. Practicing Critical Reflection: A Resource Handbook. London: Open University Press.

Gibbs, G. 1988. Learning by Doing: A Guide to Teaching and Learning Methods. Oxford: Oxford Brookes University.

Goodley, D. 2007. "Towards Socially Just Pedagogies: Deleuzoguattarian Critical Disability Studies." International Journal of Inclusive Education 11 (3): 317-34. https://doi. org/10.1080/13603110701238769

Grant, A., P. Kinnersley, E. Metcalf, R. Pill, and H. Houston. 2006. "Students' Views of Reflective Learning Techniques: An Efficacy Study at a UK Medical School." Medical Education 40 (4): 379-88. https:// doi.org/10.1111/j.1365-2929.2006.02415.x

Habermas, J. 1971. Knowledge and Human Interests. Translated by J. Shapiro. Boston: Beacon Press.

Haraway, D. 2000. How Like a Leaf: An Interview with Thyrza Nichols Goodeve. New York: Routledge.

Haraway, D. 2016. Staying with the Trouble. Making Kin in the Chthulucene. Durham: Duke University Press. https://doi.org/10.1215/9780822373780

Hargreaves, J. 2004. "So How Do You Feel about That? Assessing Reflective Practice." Nurse Education Today 24 (3): 196-201. https://doi.org/10.1016/j.nedt.2003.11.008

Hartman, N., H. Kathard, G. Perez, S. Reid, J. Irlam, G. Gunston, V. Janse Van Rensburg, V. Burch, M. Duncan, D. Hellenberg, I. Van Rooyen, M. Smouse, C. Sikakane, E. Badenhorst, and B. Ige. 2012. "Health Sciences Undergraduate Education at UCT: A Story of Transformation." South African Medical Journal 102 (6): 477-80. https://doi.org/10.7196/SAMJ.5680

Hatton, N., and D. Smith. 1995. "Reflection in Teacher Education-Towards Definition and Implementation." Teaching and Teacher Education 11 (1): 33-49. https://doi.org/10.1016/0742-051X(94)00012-U

Odhiambo, A. 2011. "'Stop Making Excuses': Accountability for Maternal Health Care in South Africa." Human Rights Watch, August 8. http://www.hrw.org/reports/2011/08/08/stop-making-excuses-0 (accessed May 2, 2017).

Johns, C. 2000. Becoming a Reflective Practitioner. Oxford: Blackwell Science.

Juelskjær, M., and N. Schwennesen. 2012. "Intra-Active Entanglements: An Interview with Karen Barad." Kvinder, Koen og Forskning 21 (1-2): 10-23.

Lenz Taguchi, H. 2010. Going Beyond the Theory/Practice Divide in Early Childhood Education: Introducing an Intra-Active Pedagogy. London: Routledge.

Lenz Taguchi, H., and A. Palmer. 2013. “A More 'Livable' School? A Diffractive Analysis of the Performative Enactments of Girls' Ill-/Well-Being With(in) School Environments." Gender and Education 25 (6): 671-87. https://doi.org/10.1080/09540253.2013.829909 
Kaiser, B. M., and K. Thiele. 2014. "Diffraction: Onto-Epistemology, Quantum Physics and Critical Humanities.” Parallax 20 (3): 165-67. https://doi.org/10.1080/13534645.2014.927621

King, P. M., and K. S. Kitchener. 1994. Developing Reflective Judgment. San Francisco: Jossey-Bass.

Kleinman, A. 2012. "Intra-Actions: Interview with Karen Barad.” Mousse 34: 76-81.

Kneebone, R. 2002. "Total Internal Reflection: An Essay on Paradigms.” Medical Education 36 (6): 51418. https://doi.org/10.1046/j.1365-2923.2002.01224.x

Kolb, D. A. 1984. Experiential Learning: Experience as the Source of Learning and Development. Englewood Gliffs: Prentice Hall.

Kreber, C. 2004. "An Analysis of Two Models of Reflection and Their Implications for Educational Development." International Journal for Academic Development 9 (1): 29-49. https://doi. org/10.1080/1360144042000296044

Mackintosh, C. 1998. "Reflection: A Flawed Strategy for the Nursing Profession." Nurse Education Today 18 (7): 553-57. https://doi.org/10.1016/S0260-6917(98)80005-1

MacLure, M. 2013. "Classification or Wonder? Coding as an Analytic Practice in Qualitative Research." In Deleuze and Research Methodologies, edited by R. Coleman and J. Ringrose, 164-83. Edinburgh: Edinburgh University Press.

Mamede, S., H. G. Schmidt, and J. C. Penaforte. 2008. "Effects of Reflective Practice on the Accuracy of Medical Diagnoses." Medical Education 42 (5): 468-75. https://doi.org/10.1111/j.13652923.2008.03030.x

Mann, K., J. Gordon, and A. McLeod. 2009. "Reflection and Reflective Practice in Health Professions Education: A Systematic Review." Advances in Health Sciences Education 14: 595-621. https://doi. org/10.1007/s10459 00790902

Manning, E. 2012. Always More than One: Individuation's Dance. Durham: Duke University Press. https:// doi.org/10.1215/9780822395829

Massumi, B. 1987. Notes on the Translation and Acknowledgments in A Thousand Plateaus: Capitalism and Schizophrenia, by G. Deleuze and F. Guattari. Minneapolis: University of Minnesota Press.

Massumi, B. 2002. Parables for the Virtual: Movement, Affect, Sensation. Durham: Duke University Press. https://doi.org/10.1215/9780822383574

Massumi, B. 2015. Politics of Affect. Cambridge: Polity.

MacLure, M. 2013. "Researching without Representation? Language and Materiality in Post-Qualitative Methodology." International Journal of Qualitative Studies in Education 26 (6): 658-67. https://doi. org/10.1080/09518398.2013.788755

McMullan, M. 2006. "Students' Perceptions on the Use of Portfolios in Pre-Registration Nursing Education: A Questionnaire Survey." International Journal of Nursing Studies 43 (3): 333-43. https://doi. org/10.1016/j.ijnurstu.2005.05.005 
Mezirow, J. 1990. "How Critical Reflection Triggers Transformative Learning." In Fostering Critical Reflection in Adulthood: A Guide to Transformative Emancipatory Learning, edited by J. Mezirow, 1-20. San Francisco: Jossey-Bass.

Moon, J. 2001. "Reflection in Higher Education Learning." PDP Working Paper 4, LTSN Generic Centre. https://www.cumbria.ac.uk/media/university-of-cumbria-website/content-assets/public/er/ documents/admissions/interviewdocs/Moon2001ReflectivePracticeInterview-1.pdf (accessed May 4, 2017).

Moje, E. B. 2007. "Developing Socially Just Subject-Matter Instruction: A Review of the Literature on Disciplinary Literacy Teaching." Review of Research in Education 31: 1-44. https://doi. org/10.3102/0091732X07300046001

Murphy, J. I. 2004. "Using Focused Reflection and Articulation to Promote Clinical Reasoning: An Evidence-Based Teaching Strategy." Nursing Education Perspectives 25 (5): 226-31.

Palmer, A. 2011. “'How Many Sums Can I Do?' Performative Strategies and Diffractive Thinking as Methodological Tools for Rethinking Mathematical Subjectivity." Reconceptualizing Educational Research Methodology 1 (1): 3-18. https://doi.org/10.7577/rerm.173

Ringrose, J., and E. Renold. 2014. “"F**k Rape!’: Exploring Affective Intensities in a Feminist Research Assemblage." Qualitative Inquiry 20 (6): 772-80. https://doi.org/10.1177/1077800414530261

Rai, L. 2006 "Owning (up to) Reflective Writing in Social Work Education." Social Work Education 25 (8): 785-97. https://doi.org/10.1080/02615470600915845

Rogers, R. R. 2001. "Reflection in Higher Education: A Concept Analysis." Innovative Higher Education 26 (1): 37-57. https://doi.org/10.1023/A:1010986404527

Rolfe, G., D. Freshwater, and M. Jasper. 2001. Critical Reflection for Nursing and the Helping Professions: A User's Guide. London: Palgrave Macmillan.

Sandars, J. 2009. "The Use of Reflection in Medical Education: AMEE Guide No. 44.” Medical Teacher 31 (8): 685-95. https://doi.org/10.1080/01421590903050374

Schön, D. 1987. Educating the Reflective Practitioner. San Francisco: Jossey-Bass.

Sellers, M. 2013. Young Children Becoming Curriculum: Deleuze, Te Wharriki and Curricular Understandings. London: Routledge.

Seibert, K. W., and M. W. Daudelin. 1999. The Role of Reflection in Managerial Learning: Theory, Research, and Practice. Westport: Quorum.

Slater, J. 2012. "Self-Advocacy and Socially Just Pedagogy." Disability Studies Quarterly 32 (1). ISSN 2159-8371. http://dsq-sds.org/article/view/3033/3061 (accessed March 2, 2017).

Song, P., and R. Stewart. 2012. "Reflective Writing in Medical Education." Medical Teacher 34 (11): 95566. https://doi.org/10.3109/0142159X.2012.716552

Vannini, P. 2015. Non-Representational Methodologies Re-Envisioning Research. New York: Routledge. 
Vivian, L., C. Naidu, J. Keikelame, and J. Irlam. 2011. "Medical Students' Experiences of Professional Lapses and Patient Rights Abuses in a South African Health Sciences Faculty." Academic Medicine 86 (10): 1282-287. https://doi.org/10.1097/ACM.0b013e31822be4b8

Wear, D., J. Zarconi, and N. Dhillon. 2011. "Teaching Fearlessness: A Manifesto.” Education for Health 24 (3): $668-75$.

Wear, D., J. Zarconi, R. Garden, and T. Jones. 2012. "Reflection in/and Writing: Pedagogy and Practice in Medical Education." Academic Medicine 87 (5): 603-609. https://doi.org/10.1097/ ACM.0b013e31824d22e9

Wald, H. S., and S. P. Reis. 2010. "Beyond the Margins: Reflective Writing and Development of Reflective Capacity in Medical Education.” Journal of General Internal Medicine 25 (7): 746-49. https://doi. org/10.1007/s11606-010-1347-4

Zembylas, M. 2006. "Witnessing in the Classroom: The Ethics and Politics of Affect." Educational Theory 56 (3): 305-24. https://doi.org/10.1111/j.1741-5446.2006.00228.x

Zembylas, M. 2012. “Critical Pedagogy and Emotion: Working through 'Troubled Knowledge' in Posttraumatic Contexts." Critical Studies in Education 19: 1-14.

Zembylas, M. 2013. "Revisiting the Gramscian Legacy on Counter-Hegemony, the Subaltern and Affectivity: Toward an Emotional Pedagogy of Activism in Higher Education." CriSTaL 1 (1): 1-21. https://doi.org/10.14426/cristal.v1i1.2 